\title{
APPLYING CARBON FOOTPRINT METHOD POSSIBILITIES TO THE SUSTAINABLE DEVELOPMENT OF SPORTS TOURISM
}

\author{
HRVOJE GROFELNIK ${ }^{1}$, MARKO PERIĆ ${ }^{1} \&$ NICHOLAS WISE ${ }^{2}$ \\ ${ }^{1}$ University of Rijeka, Croatia \\ ${ }^{2}$ Liverpool John Moores University, UK
}

\begin{abstract}
Tourism generates diverse and complex economic, socio-cultural and environmental impacts on space. Tourism organizers and service providers tend to emphasize the positive effects, and often underestimate or neglect negative environmental impacts. The environmental impact of tourism is clearly visible in the transportation of tourists from their homes to their destinations and back, thus generating significant carbon dioxide $\left(\mathrm{CO}_{2}\right)$ emissions that directly participate in global warming. In order to determine the intensity of the impact of transport (for tourism purposes) on the environment, or more specifically on $\mathrm{CO}_{2}$ emissions, the Carbon Footprint method (CF) is increasingly applied in modern scientific research. The possibilities of CF research in the form of case studies can be monitored in an increasing number and in various fields of research, confirming the value of the method. This review paper analyses the development and application of the CF method in the sustainable development of tourism and specifically sports tourism. By reviewing and analysing the relevant $\mathrm{CF}$ literature represented in the WoSCC database, this paper presents the basics of the scientific methodology of $\mathrm{CF}$ and its development and application from the aspect of sustainable development, with particular emphasis on the application of CF in measuring the environmental impact of tourism. The research points out the potential contribution of future CF research and complement methods in the overall picture of environmental burden. This should give an agenda and impetus for future research of sustainable development within the topic of the environmental burden generated by tourism.
\end{abstract}

Keywords: sustainable development, ecological footprint, carbon footprint, tourism, sport tourism.

\section{INTRODUCTION}

Tourism generates diverse and complex economic, socio-cultural and environmental impacts. In the context of sustainable development, in general, and tourism in particular, it is possible to distinguish two social groups with opposite positions from which they observe the environment and tourism. The first group are tourism organizers and service providers, who usually emphasize the positive effects and often underestimate or neglect the negative environmental impacts. The second group are people with high environmental awareness, is gaining influence, especially among tourists who have higher education attainment and higher income levels [1], [2]. Reconciling the views of the two groups is a development challenge for tourism in the near future, and an argumentative social debate based on scientifically learned knowledge is probably the way to bring the two groups closer together to formulate development strategies and models for environmentally sustainable tourism development. In the economic context of sustainable development, tourism (with about $10 \%$ of world GDP) is a key contributor of the modern global economic system [3]. In recent decades, the scientific and professional public has been increasingly following a trend that can be described by the rise of environmental and climate change research, which is also evident in the increasing number of scientific papers addressing the environmental impact of tourism [4]. Tourism has a direct or indirect impact on the environment through various physical interventions in space (infrastructure), generation of solid and liquid waste and gas emissions. Transportation of tourists from their homes to their destinations and back 
generates significant carbon dioxide $\left(\mathrm{CO}_{2}\right.$, carbon) emissions that directly participate in contemporary anthropogenic global warming. In order to determine the intensity of the impact of transport (for tourism purposes) on the environment, or more specifically on carbon emissions, the Carbon Footprint method (CF) is increasingly applied in modern scientific research.

The aim of this paper is to review and synthesise papers that cover the issue of CF within the sustainable development of the tourism industry, and in particular with regard to the development of sports tourism which is proved to be one the most prosperous types of tourism [5], [6]. To accomplish this, we define the following research questions:

- Research Question 1: What is the state of the art in published tourism CF papers?

- Research Question 2: What approaches and methods or frameworks have been used to determine/measure the environmental burden of carbon emissions?

An overview of the CF research in tourism in this paper will systematize this growing area of scientific interest and point out the possibilities of complementing the overall picture of environmental burden with topics that have not yet been addressed and serve as an impetus for future research and complementing the image of sustainable development within the theme of environmental burden generated by tourism.

\section{CONCEPTS AND BASIC FACTS OF THE SCIENTIFIC FIELD}

The CF method is part of a broader methodological approach to determining the Ecological Footprint (EF) as one of the methodologies that have been developed over the last thirty years to determine current global or local load on space. In one of the early papers [7], EF is defined as a measurement tool that allows for determining the degree of utilization of a resource base and the possibility of assimilation of waste to a particular population on a particular surface. The methodology was designed to calculate EF by surface for a given population encompasses a wide range of human activities and their environmental impacts. Therefore, the EF methodology can be used integrally for the whole spatial system and its activities or partially. Partial use can be applied to isolated physical spatial units, but also to certain functional parts of spatial systems, such as for example individual activities or aspects of activities that can be explored as separate units in the context of sustainable development. In WoSCC, the first papers to determine the bioabsorption basis of $\mathrm{CO} 2$ as the basis for developing the CF method were published by Cienciala et al. in 1998 [8] while the CF method has been using the WoSCC database under this name since 2007 [9]. The possibilities of CF research in the form of case studies that can be tracked in increasing numbers in various fields of research to date confirm the value of the method This review paper analyses the development and application of the CF method in the sustainable development of tourism, and in particular sports tourism. The scientific public's interest in the CF method is increasing as global awareness of the environmental burden caused primarily by anthropogenic carbon emissions from the use of fossil fuels with specific effects on contemporary climate change.

The connection between sports, tourism and CF is multifaceted. Sport is a performanceoriented activity and is an important content of stay in a destination. Many tourists, when in a destination, decide to actively (as competitors) or passively (as spectators) participate in various sports activities. Additionally, sport increasingly becomes a tourist attraction [10] and the main motive for travelling to a certain tourist destination. This laid the foundations for the development of sports tourism and many authors discussed this phenomenon as being a unique interaction of places, activities, time and people [5], [10]-[12]. Today, it is argued 
that between $25 \%$ and $30 \%$ of the world's tourism economy is related to sport, that sports tourism is one of the fastest growing sectors in travel industry and shows no sign of slowing down [13], [14].

While there are numerous types of sports tourism, sport events are the most popular manifestation of sports tourism [15], [16]. Sport events, as well as sport activities in general, attract tourists (as participants or spectators) and could serve as a catalyst for tourism development if leveraged properly. Besides the impact on tourism and economy in general, they create diverse and intense socio-cultural and environmental impacts on a host community [17], [18]-[20]. While positive impacts are accentuated, negative environmental impacts in particular are often underestimated or neglected [17], [21]. Negative environmental event impacts such as environmental damage, increased amount of litter, waste, air pollution (e.g. transport related carbon dioxide emissions) and noise levels all happen within a destination.

\section{METHODOLOGY}

The study of CF in tourism and sport tourism is a relatively new area of academic research involving multiple disciplines, methodological approaches and topics. Based on this fact as well as on this study's objectives, systematic quantitative literature review is applied [22][24]. A systematic quantitative literature review follows a structured method to address particular research questions and aims for methodological transparency and reliability as well as systematic and comprehensive search on a specified topic. It may also incorporate quasistatistical approaches in order to categorise, quantify, and identify trends in extant research thus assisting in highlighting research gaps and possible streams of future research [23], [25]-[27].

In conducting the review, a multistep process was used. First, a comprehensive review was conducted in December 2019 and January 2020 through searching the Web of Science Core Collection (WoSCC) database for publications that contain the term Tourism and Carbon Footprint in the title, abstract or keywords from the early publishing dates to December 2019. WoSCC have international coverage, include top rated publications and are therefore largest databases of peer-reviewed literature. In view of the scope of this review paper, a selection of publications by the WoSCC database was started according to the Topic criterion with the key word tourism and 75,362 papers were found in database. After using the and function for subjoin Carbon Footprint in the WoSCC database a total of 179 publications were found. Initial cursory analysis of selected publications revealed that many of the selected papers were not research papers and/or that they deal with the CF concept in a trivial and marginal way. These papers were therefore excluded from further analysis.

However, when it comes to publications focused on sport tourism (searching for the terms tourism and carbon footprint and sport in the title, abstract or keywords) the sample was reduced to only seven papers. Two out of seven papers had not considered the CF of sport tourism like the object of the study. For this reason, using these particular papers' list of references as a guide, further search of the database is conducted, and additional 8 papers is found to be relevant (although they do not have the term Tourism and Carbon Footprint in the title, abstract or keywords). The final sample consisted of 13 publications closely related to the CF in sport tourism, all of which papers published in scientific journals.

Due to the relatively small number of articles included in the study, the authors stored, coded, and categorized papers manually. In order to classify papers into categories, direct extraction and/or inductive interpretation methods were implemented (see Thomson et al. [26]). Frequency of appearance of particular categories was searched within the selected papers. Inductive method in interpretations allowed new findings to emerge through the data. 
The categorisation process was iterative to ensure consistency of the categorisation of articles in the sample.

\section{RESULTS AND DISCUSSION}

4.1 Review of papers with topic on carbon footprint in tourism

Analysing the dynamics of CF research papers in tourism at WoSCC database it was found that the first paper using words CF was published by in 2007 [28], and after sporadic work in the initial phase of developing the CF method after 2010 a positive upward trend on an annual basis is visible (Fig. 1). Because CF method derive from the EF concept in the initial phase of developing CF concept research, various authors used name of EF.

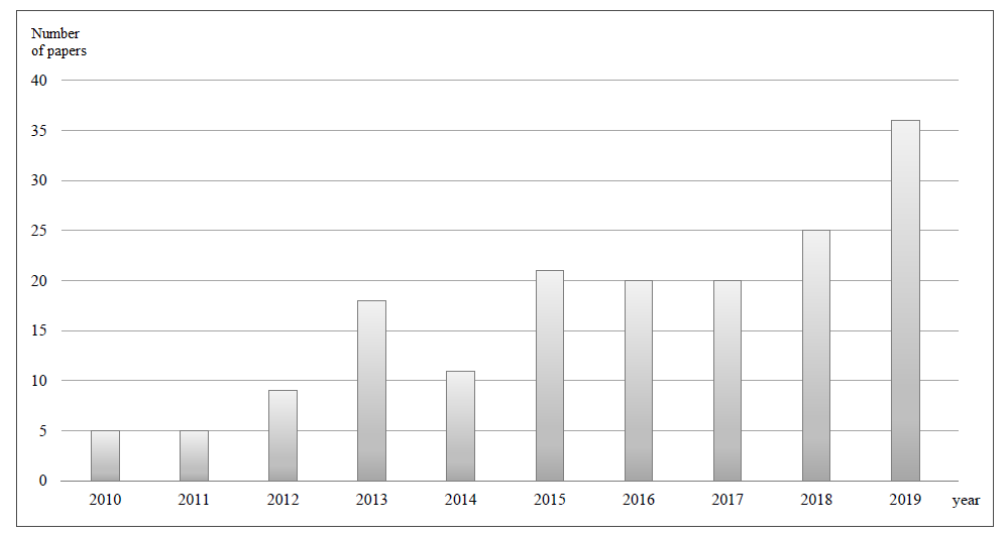

Figure 1: Dynamics of tourism CF research papers referred in WoSCC 2010-2019.

As mentioned above, the search of the WoSCC database resulted in 179 publications, most of which (139) are articles published in scientific journals. In addition, there are 17 papers published in conference proceedings, six reviews, five book chapters, two books and six other scientific publications.

Looking at the spatial interest of the researcher (Table 1), it is evident that there is no homogeneity at the world level. Several large and developed countries such as Australia, China, the UK and Sweden are leading the research field of CF in tourism. Notably, there is a lack of research from large and developed countries such as USA and Japan. This suggests that Australia and the UK have a broader base of the researchers, while in the rest of the countries/universities have individual researches on tourism CF.

By analysing the WoSCC database for CF method in tourism over two decades, only four scientific journals stands out by a number of papers published. These four journals have published more than ten papers each and they account for $38 \%$ of the total number of papers covered by this analysis. Journal with the most published papers on CF of tourism is Journal of Sustainable Tourism (22 articles, Q1), then Journal of Cleaner Production (18 articles, Q1), then Sustainability (16 articles, Q2) and Tourism Management (12 articles, Q1).

A content analysis of the titles of the identified papers reveal the following terms that are repeated more than five times: Tourism with 98 citations, Carbon with 91, Carbon footprint 
Table 1: Spatial distribution of papers with the most active authors in the field.

\begin{tabular}{|l|l|l|}
\hline \multirow{2}{*}{ State } & $\begin{array}{l}\text { University with more than three } \\
\text { published papers }\end{array}$ & $\begin{array}{l}\text { Author with more than } \\
\text { three published papers }\end{array}$ \\
\hline \multirow{4}{*}{ Australia } & University of Queensland (9 papers) & Dolnicar, S. (5 papers) \\
\cline { 2 - 3 } & Griffith University (7 papers) & Becken, S. (4 papers) \\
\cline { 2 - 3 } China & James Cook University (4 papers) & - \\
\cline { 2 - 3 } & $\begin{array}{l}\text { Chinese Academy of Sciences (8 papers) } \\
\text { Resources Research CAS (4 papers) }\end{array}$ & - \\
\cline { 2 - 3 } & Sichuan University (4 papers) & - \\
\hline \multirow{3}{*}{ UK } & Bournemouth University (15 papers) & $\begin{array}{l}\text { Filimonau, V. (13 papers), } \\
\text { Robbins, D. (5 papers), } \\
\text { Dickinson, J. (4 papers) }\end{array}$ \\
\hline \multirow{2}{*}{ Hong Kong } & $\begin{array}{l}\text { Linnaeus University (7 papers) } \\
\text { (6 papers) }\end{array}$ & Hall, C.M. (4 papers) \\
\cline { 2 - 3 } Taiwan & $\begin{array}{l}\text { National Cheng Kung University } \\
\text { (6 papers) }\end{array}$ & Gossling, S. (9 papers) \\
\hline Canada & University of Waterloo (4 papers) & Scot, D. (4 papers) \\
\hline Netherlands & $\begin{array}{l}\text { Breda University of Applied Sciences } \\
\text { (4 papers) }\end{array}$ & - \\
\hline
\end{tabular}

with 42, Carbon emission/s 14, and Transportation with 6. From the above it is evident that Carbon footprint in tourism is linked with transport as the largest emitter of $\mathrm{CO}_{2}$ related to today's global tourism.

Further, a focus on methodology for CF calculation was considered. In-depth analysis of papers revealed that many of the selected papers were not research papers. More precisely, 37 papers are purely theoretical/conceptual studies (that study the basics of CF in tourism), 43 papers are empirical using different data sources, and 99 papers are dominantly theoretical with marginal empirical part. For this reason, only 43 empirical papers are taken for further analysis and others were therefore excluded.

Among the analysed papers 43 empirical papers were singled out of which 25 used topdown approach to collect the data with secondary sources of data in which the most used and important are methods: (1) Tourism Satellite Account (TSA), e.g. [29]; (2) Input-output model (IO), e.g. [30]; (3) Life cycle assessment (LCA), e.g. [31]. In the context of tourism CF methods data collection the main challenge is their capability to keep track of indirect carbon emissions associated with the products and services hidden in the supply chain. To resolve this problem many researchers used input-output analysis (IO). IO, however, suffers from a limited scope of application - primarily at macro scales, such as national industrial sectors, national economies, national tourism industries and national tourist markets [32]. To reduce the problem of indirect carbon emissions, over time a method of LCA has evolved in which both the direct and the indirect carbon emissions for energy and material inputs of a goods and services over its life cycle are included.

Additionally, 18 papers used bottom-up approaches, using primary sources of data obtained from surveys of tourists or economic operators [33], institutions managing an area 
[34] or conducted in direct contact with transport companies [35]. The bottom-up approach used primary data sources to provide accurate and more secure outcomes. However, the weakness of such an approach is in the organisation and duration of data collection, spatial and partial system coverage of such research. It would take many case studies to get the overall picture, which would require a lot of researchers and time for data collection and processing.

\subsection{Review of papers with topic on carbon footprint of sports tourism}

Our search resulted in 13 scientific journals directly related to the CF in sport tourism (Table 2 ). What is evident from the Table 2 is the variety of examined sports and events as well as approaches to measure CF. While the type of sporting events range from local community based sporting events (e.g. ice hockey [36] or university athletics [37]) to global mega events (e.g. FIFA World Cup or Olympic Games [38], [39]). It was determined that most studies focused on internationally popular sports like soccer, American football, running, cycling and athletics.

Considering the authors and their affiliations, it is not surprise that these events were held in large and developed countries like the UK, USA or Canada. Despite being a large and competitive country, and the fact that many authors who studied CF were from China, when it comes to sporting events, there were not any studies from China. Additionally, in most of the previous studies, data were collected from event attendees, both competitors (athletes or teams) and spectators. While in first studies, authors mostly applied IO analysis, recent studies favoured LCA and other innovative methods.

\section{CONCLUSION}

The development of tourism in modern times is increasingly diverse, its environmental impact is growing, and the developmental dynamics of environmental tourism research can be clearly observed in the number of papers referred in the WoSCC database. In the last three decades, the development of the EF and specifically CF method has followed the contemporary development of the awareness of the scientific and general social public about the need for environmental protection and the need for sustainable development. In this context, in order to answer the research questions raised at the outset, this paper reviewed the development and state of the art of the CF method in tourism and sport tourism in particular.

Providing a systematization of this growing area of scientific interest, this paper presents the basics of the CF scientific methodology. CF method initially derives from the EF concept, and in the initial phase of CF research various authors used name of EF. Expanding the search on other databases, conducting more detailed content analysis of other publications in the database, and inclusion of additional terms such as Ecological Footprint or Carbon Emissions in our search would certainly result in other relevant papers. This can guide future studies in this fast-growing area of research.

The spatial scope of the analysed papers was different (from local to global level) as well as applied approaches and methodologies. Two basic frameworks for calculating CF in tourism have been identified: a top-down analysis dominantly using secondary data sources and a bottom-up analysis using primary data sources. Despite the advance in the development of $\mathrm{CF}$ determination methods, the problem of indirect $\mathrm{CF}$ in general and indirect $\mathrm{CF}$ of tourism is still not fully resolved. The dominance of theoretical/conceptual scientific papers among the published papers has been observed, and in order to further development of the $\mathrm{CF}$ field, it is necessary to make steps towards studying more cases at the local and regional 
Table 2: Relevant CF sport tourism papers referred in WoSCC database.

\begin{tabular}{|c|c|c|c|}
\hline Author & Sport/Event & Country & Method/s \\
\hline Collins et al. [40] & $\begin{array}{l}\text { Football (soccer), } \\
\text { FA Cup Final }\end{array}$ & UK & $\begin{array}{l}\text { - Input-output (IO) } \\
\text { - Ecological footprint (EF) }\end{array}$ \\
\hline Jones [41] & $\begin{array}{l}\text { Rally, } \\
\text { World Rally } \\
\text { Championship }\end{array}$ & UK & $\begin{array}{l}\text { - Input-output (IO) } \\
\text { - Tourism satellite accounting } \\
\text { - Interviews }\end{array}$ \\
\hline Collins et al. [38] & $\begin{array}{l}\text { Multiple sports, } \\
\text { Summer Olympic } \\
\text { Games and FIFA } \\
\text { World Cup }\end{array}$ & UK & $\begin{array}{l}\text { - Input-output (IO) } \\
\text { - Ecological footprint (EF) } \\
\text { - Survey method } \\
\text { - Information from the event sponsors }\end{array}$ \\
\hline Chard and Mallen [36] & $\begin{array}{l}\text { Ice hockey, } \\
\text { local matches }\end{array}$ & Canada & $\begin{array}{l}\text { - Interviews } \\
\text { - Carbon footprint calculators (CarbonZero } \\
\text { and PlanetAir) }\end{array}$ \\
\hline Collins et al. [42] & $\begin{array}{l}\text { Cycling, } \\
\text { UK Stages of Tour } \\
\text { de France }\end{array}$ & UK & $\begin{array}{l}\text { - Input-output (IO) } \\
\text { - Ecological footprint (EF) } \\
\text { - Survey method } \\
\text { - Carbon footprint (CF) }\end{array}$ \\
\hline $\begin{array}{l}\text { Krugell and Saayman } \\
\text { [43] }\end{array}$ & $\begin{array}{l}\text { Marathon, } \\
\text { world race }\end{array}$ & $\begin{array}{l}\text { South } \\
\text { Africa }\end{array}$ & $\begin{array}{l}\text { - Survey method } \\
\text { - Regression analysis }\end{array}$ \\
\hline Dolf and Teehan [44] & $\begin{array}{l}\text { Multiple sports, } \\
\text { University sports } \\
\text { events }\end{array}$ & Canada & $\begin{array}{l}\text { - Life Cycle Assessment (LCA) method } \\
\text { - Survey method }\end{array}$ \\
\hline Edwards et al. [37] & $\begin{array}{l}\text { Athletics, } \\
\text { University sports } \\
\text { events }\end{array}$ & USA & $\begin{array}{l}\text { - Survey method } \\
\text { - Student observers } \\
\text { - Information from event organizers } \\
\text { - Life cycle assessments (LCA + SimaPro } \\
\text { LCA software) }\end{array}$ \\
\hline Scrucca et al. [45] & $\begin{array}{l}\text { Orienteering, } \\
\text { World } \\
\text { Championship }\end{array}$ & Italy & $\begin{array}{l}\text { - Carbon footprint (CF) analysis } \\
\text { - Information from organizers, athletes and } \\
\text { accommodation } \\
\text { - Authors proposes a method of summary } \\
\text { indicator }\end{array}$ \\
\hline Pereira et al. [39] & $\begin{array}{l}\text { Football (soccer), } \\
\text { FIFA World Cups }\end{array}$ & $\begin{array}{l}\text { Multiple } \\
\text { states }\end{array}$ & $\begin{array}{l}\text { - Facility Location Problem (FLP) - } \\
\text { mathematical modelling method for } \\
\text { determining the best location with lowest } \\
\text { transportation CF }\end{array}$ \\
\hline Triantafyllidis et al. [46] & $\begin{array}{l}\text { American football, } \\
\text { Collegiate sport } \\
\text { events }\end{array}$ & USA & $\begin{array}{l}\text { - Survey method } \\
\text { - Independent t-Test } \\
\text { - ANOVA analysis }\end{array}$ \\
\hline Wicker [6] & Multiple sports & Germany & $\begin{array}{l}\text { - Survey method } \\
\text { - Regression analysis }\end{array}$ \\
\hline Pereira et al. [47] & $\begin{array}{l}\text { Football (soccer), } \\
\text { English Premier } \\
\text { League matches }\end{array}$ & UK & $\begin{array}{l}\text { - Carbon footprint (CF) assessment method } \\
\text { developed by the UK's DEFRA } \\
\text { - Questionnaire }\end{array}$ \\
\hline
\end{tabular}

levels. This is especially important if policies are going to be realised locally so that development strategies at the local and regional levels can embrace CF from the bottom-up. In the analysis, we noticed the need to improve empirical CF researches with field case studies that would upgrade the overall picture of measuring the environmental load. Furthermore, the overall picture of the pressures put on the environment will be much upgraded by conducting a greater number of empirical studies of CF tourism and sports tourism. Based on greater number of works based on primary source data in future it is possible to create a wider base that will help in creating sustainable development policies on a scientific basis. 
Regarding the limitations of this study, we searched only WoSCC database. It is also possible that there were papers in the WoSCC database that deal with CF in tourism and/or sport tourism but they did not use the terms tourism, carbon footprint and sport in the title, abstract and keywords. But this selection of papers indexed in WoSCC are well-regarded for peer-review rigour and assessing these sources guarantees that the authors of this study are assessing papers that are reaching the widest possible audience.

\section{ACKNOWLEDGEMENT}

This paper was funded under the project line ZIP UNIRI of the University of Rijeka, for the project ZIP-UNIRI-116-2-19.

\section{REFERENCES}

[1] Liu, K.S., Hsueh, S.L. \& Chen, H.Y., Relationship between environmental education, environmental attitudes, and behavioral intentions toward ecolodging. Open House International, 43(2), pp. 5-12, 2018.

[2] Dodds, R., Graci, S.R. \& Holmes, M., Does the tourist care? A comparison of tourists in Koh Phi Phi, Thailand and Gili Trawangan, Indonesia. Journal of Sustainable Tourism, 18(2), pp. 207-222, 2010. https://doi.org/10.1080/09669580903215162.

[3] Petcu, M.A. \& Cismasu, I.D., Tourism: A contribution to the sustainable economic growth. Quality-Access to Success, 20, pp. 460-466, 2019.

[4] Velasco-Muñoz, J.F., Aznar-Sánchez, J.A., Belmonte-Ureña, L.J. \& López-Serrano, M.J., Advances in water use efficiency in agriculture: A bibliometric analysis. Water, 10, pp. 377, 2018. https://doi.org/10.3390/w10040377.

[5] Weed, M. \& Bull, C., Sports Tourism: Participants, Policy and Providers, 2nd ed., Elsevier: Oxford, 2009. https://doi.org/10.4324/9780080942117.

[6] Wicker, P., The carbon footprint of active sport participants. Sport Management Review, 22(4), pp. 513-526, 2019.

[7] Wackernagel, M. \& Rees, W.E., Our Ecological Footprint: Reducing Human Impact on the Earth, New Society Publishers: Philadelphia, 160 pp., 1996.

[8] Cienciala, E., Running, S.W., Lindroth, A., Grelle, A. \& Ryan, M.G., Analysis of carbon and water fluxes from the NOPEX boreal forest: Comparison of measurements with FOREST-BGC simulations. Journal of Hydrology, 212(1-4), pp. 62-78, 1998. https://doi.org/10.1016/S0022-1694(98)00202-9.

[9] Christen, K., The carbon footprint of transportation fuels. Environmental Science and Technology, 41(19), pp. 6636-6636, 2007.

[10] Hinch, T.D. \& Higham, J., Sport tourism: A framework for research. International Journal of Tourism Research, 3, pp. 45-58, 2001. https://doi.org/10.1002/1522-1970(200101/02)3:1<45::AID-JTR243>3.0.CO;2-A.

[11] Gammon, S. \& Robinson, T., Sport and tourism: a conceptual framework. Journal of Sport Tourism, 4(3), pp. 11-18, 1997. https://doi.org/10.1080/14775080306236.

[12] Sobry, C., Liu, X. \& Li, J., Sport tourism: Contribution to a definition and categorization. Acta Turistica, 28(1), pp. 7-26, 2016.

[13] Hoye, R. \& Parent, M.M., The SAGE Handbook of Sport Management. SAGE: Thousand Oaks, 2016, ISBN 978-1-4739-5923-1.

[14] Parker, R., The remarkable growth of sport tourism. Human Kinetics, 2019. https://humankinetics.me/2019/04/04/the-remarkable-growth-of-sport-tourism/. Accessed on: 11 Feb. 2020.

[15] Getz, D. \& Page, S.J., Progress and prospects for event tourism research. Tourism Management, 52, pp. 593-631, 2016. https://doi.org/10.1016/j.tourman.2015.03.007. 
[16] Roche, S., Spake, D.F. \& Joseph, M., A model of sporting event tourism as economic development. Sport, Business and Management: An International Journal, 3(2), pp. 147-157, 2013. https://doi.org/10.1108/20426781311325078.

[17] Ahmed, T.S.A.A., A triple bottom line analysis of the impacts of the Hail International Rally in Saudi Arabia. Managing Sport and Leisure, 22(4), pp. 276-309, 2017. https://doi.org/10.1080/23750472.2018.1465841.

[18] Perić, M., Đurkin, J. \& Wise, N., Leveraging small-scale sport events: Challenges of organising, delivering and managing sustainable outcomes in rural communities, the case of Gorski kotar, Croatia. Sustainability, 8(12), pp. 1337, 2016. https://doi.org/10.3390/su8121337.

[19] Schulenkorf, N. \& Edwards, D., Maximizing positive social impacts: Strategies for sustaining and leveraging the benefits of intercommunity sport events in divided societies. Journal of Sport Management, 26(5), pp. 379-390, 2012. https://doi.org/10.1123/jsm.26.5.379.

[20] Wise, N., Outlining triple bottom line contexts in urban tourism regeneration. Cities, 53, pp. 30-34, 2016. https://doi.org/10.1016/j.cities.2016.01.003.

[21] Perić, M., Estimating the perceived socio-economic impacts of hosting large-scale sport tourism events. Social Sciences, 7(10), pp. 176, 2018. https://doi.org/10.3390/socsci7100176.

[22] Cooper, H., Hedges, L. \& Valentine, J., The Handbook of Research Synthesis and Meta-Analysis, 2nd ed., Russell Sage Foundation: New York, 2009.

[23] Pickering, C. \& Byrne, J., The benefits of publishing systematic quantitative literature reviews for $\mathrm{PhD}$ candidates and other early career researchers. Higher Education Research and Development, 33(3), pp. 534-548, 2014, https://doi.org/10.1080/07294360.2013.841651.

[24] Wakefield, A., Synthesising the literature as part of a literature review. Nursing Standard, 29(29), pp. 44-51, 2015. https://doi.org/10.7748/ns.29.29.44.e8957.

[25] Onwuegbuzie, A. \& Frels, R., Seven Steps to a Comprehensive Literature Review: A Multimodal and Cultural Approach, SAGE, 2016.

[26] Thomson, A., Cuskelly, G., Toohey, K., Kennelly, M., Burton, P. \& Fredline, L., Sport event legacy: A systematic quantitative review of literature. Sport Management Review, 22(3), pp. 295-321, 2019. https://doi.org/10.1016/j.smr.2018.06.011.

[27] Whittemore, R. \& Knafl, K., The integrative review: Updated methodology. Methodological Issues in Nursing Research, 52(5), pp. 546-553, 2005. https://doi.org/10.1111/j.1365-2648.2005.03621.x.

[28] Fawkes, S., Carbon dioxide emissions resulting from space tourism. Journal of the British Interplanetary Society, 60, pp. 409-413, 2007.

[29] Wu, D.C.G., Liu, J.Y., Song, H.Y., Liu, A.Y. \& Fu, H., Developing a web-based regional tourism satellite account (TSA) information system. Tourism Economics, 25(1), pp. 67-84, 2019. https://doi.org/10.1177/1354816618792446.

[30] Sun, Y.-Y., Decomposition of tourism greenhouse gas emissions: Revealing the dynamics between tourism economic growth, technological efficiency, and carbon emissions. Tourism Management, 55, pp. 326-336, 2016. https://doi.org/10.1016/j.tourman.2016.02.014.

[31] Sharp, H., Grundius, J. \& Heinonen, J., Carbon footprint of inbound tourism to Iceland: A Consumption-based life-cycle assessment including direct and indirect emissions. Sustainability, 8(11), pp. 1147, 2016. https://doi.org/10.3390/su8111147. 
[32] Filimonau, V., Dickinson, J.E., Robbins, D. \& Reddy, M.V., A critical review of methods for tourism climate change appraisal: Life cycle assessment as a new approach. Journal of Sustainable Tourism, 19(3), pp. 301-324, 2011.

https://doi.org/10.1080/09669582.2010.527345.

[33] Michailidou, A.V., Vlachokostas, C. \& Moussiopoulos, N., A methodology to assess the overall environmental pressure attributed to tourism areas: A combined approach for typical all-sized hotels in Chalkidiki, Greece. Ecological Indicators, 50, pp. 108119, 2015. https://doi.org/10.1016/j.ecolind.2014.11.006.

[34] Monz, C., D’Antonio, A., Lawson, S., Barber, J. \& Newman, P., The ecological implications of visitor transportation in parks and protected areas: Examples from research in US National Parks. Journal of Transport Geography, 51, pp. 27-35, 2016. https://doi.org/10.1016/j.jtrangeo.2015.11.003.

[35] Grofelnik, H., A regular annual sea transport carbon footprint for the islands of Cres and Lošinj. Croatian Geographical Bulletin, 77(2), pp. 73-83, 2015. https://doi.org/10.21861/HGG.2015.77.02.04.

[36] Chard, C. \& Mallen, C., Examining the linkages between automobile use and carbon impacts of community-based ice hockey. Sport Management Review, 15(4), pp. 476484, 2012. https://doi.org/10.1016/j.smr.2012.02.002.

[37] Edwards, L., Knight, J., Handler, R., Abraham, J. \& Blowers, P., The methodology and results of using life cycle assessment to measure and reduce the greenhouse gas emissions footprint of "Major Events" at the University of Arizona. The International Journal of Life Cycle Assessment, 21(4), pp. 536-554, 2016.

[38] Collins, A., Jones, C. \& Munday, M., Assessing the environmental impacts of mega sporting events: Two options? Tourism Management, 30(6), pp. 828-837, 2009. https://doi.org/10.1016/j.tourman.2008.12.006.

[39] Pereira, R.P.T., Camara, M.V.O., Ribeiro, G.M., \& Filimonau, V., Applying the facility location problem model for selection of more climate benign mega sporting event hosts: A case of the FIFA World Cups. Journal of Cleaner Production, 159, pp. 147-157, 2017.

[40] Collins, A., Flynn, A., Munday, M. \& Roberts, A., Assessing the environmental consequences of major sporting events: The 2003/04 FA Cup Final. Urban Studies, 44, pp. 457-476, 2007. https://doi.org/10.1080/00420980601131878.

[41] Jones, C., Assessing the impact of a major sporting event: The role of environmental accounting. Tourism Economics, 14(2), pp. 343-360, 2008. https://doi.org/10.5367/000000008784460382.

[42] Collins, A., Munday, M. \& Roberts, A., Environmental consequences of tourism consumption at major events: an analysis of the UK stages of the 2007 Tour de France. Journal of Travel Research, 51, pp. 577-590, 2012. https://doi.org/10.1177/0047287511434113.

[43] Krugell, W. \& Saayman, M., Running a greener race: Willingness-to-pay evidence from the Old Mutual Two Oceans Marathon in South Africa. South African Journal for Research in Sport, Physical Education and Recreation, 35(1), pp. 53-70, 2013.

[44] Dolf, M. \& Teehan, P., Reducing the carbon footprint of spectator and team travel at the University of British Columbia's varsity sports events. Sport Management Review, 18(2), pp. 244-255, 2015. https://doi.org/10.1016/j.smr.2014.06.003.

[45] Scrucca, F., Severi, C., Galvan, N. \& Brunori, A., A new method to assess the sustainability performance of events: Application to the 2014 World Orienteering Championship. Environmental Impact Assessment Review, 56, pp. 1-11, 2016. https://doi.org/10.1016/j.eiar.2015.08.002. 
[46] Triantafyllidis, S., Ries, R.J. \& Kaplanidou, K., Carbon dioxide emissions of spectators' transportation in collegiate sporting events: comparing on-campus and offcampus stadium locations. Sustainability, 10, 241, 2018.

https://doi.org/10.3390/su10010241.

[47] Pereira, R.P.T., Filimonau, V. \& Ribeiro, G.M., Score a goal for climate: Assessing the carbon footprint of travel patterns of the English Premier League clubs. Journal of Cleaner Production, 227, 167-177, 2019. 